\title{
A Review of the Challenges Militating Against Women Entrepreneurship in Developing Nations
}

\author{
Chinonye Love Moses \\ Maxwell Olokundun \\ Hezekiah Falola \\ Stephen Ibidunni
}

Augusta Amaihian

Fred Inelo

Covennt University, College of Business and Social Sciences Department of Business Management PMB 1023 Ota Ogun State Nigeria

\author{
Doi:10.5901/mjss.2016.v7n1p64
}

Abstract

The study adopted a conceptual method of research to explore the challenges facing women entrepreneurs in developing nations. The study featured an introduction, and literature review which involved a conceptual and theoretical framework. This was followed by a discussion of the challenges of women entrepreneurs as reviewed from extant literature. The study concluded with recommendations for tackling the challenges discussed as well as implications for policy makers.

\section{Introduction}

The important role women play in entrepreneurial activity has globally increased interest in female or women entrepreneurship (Fuller-Love, 2006). With particular reference to developing nations, the development of women entrepreneurship has recently gained the attention of practitioners, policy makers and even more importantly academics. This trend is consequent upon the fact women entrepreneurship is considered a power drive for economic growth and development as well as eradication of poverty (Tambunan, 2008). Research in literature has provided ample evidence that women entrepreneurship can positively impact economies particularly developing nations (Acs, Arenius, Hay, and Minniti, 2005). Winn (2005) argues that the positive impact of women entrepreneurs is evident in most nations of the world particularly because women entrepreneurs have employed their innovative capabilities to establish and effectively managed organizations of diverse sizes in various societies, and these activities have provided employment opportunities for individuals in many societies.

However, regardless of positive impact of women entrepreneurs to the development of economies globally and particularly developing nations, it is disheartening to note that they face enormous challenges which still characterize the world of business as a man's world or domain (Langwitz and Minniti 2007). Consequently entrepreneurial activities of women are still very much constrained compared to their male counterparts (Jamali, 2009; Baughn, Chua, and Neupert, 2006). Thus this study explored the challenges facing women entrepreneurs in developing nations with a view to proffering recommendations towards tackling these challenges.

\section{Research Question}

The inquiry question for this study is: what challenges militate against the development of women entrepreneurship in developing nations?

\section{Research Objective}

The objective of this study is identify in extant literature the challenges constraining the activities of women 
entrepreneurship in developing nations of the world and also attempt to provide recommendations for combating these challenges. This study will also propose a conceptual model as regards tackling the challenges faced by women entrepreneurs in developing nations.

\section{Literature Review}

\subsection{Conceptual Framework}

\subsubsection{Concept of Entrepreneurship}

Entrepreneurship is mostly associated with the concepts of innovation and creativity and it generally involves the identification and exploitation of business opportunities culminating into an enterprise or business firm (Hisrich, Peters \& Shepherd 2006). Entrepreneurship is regarded as a key ingredient required to harness human and material resources towards the achievement of growth and development of any nation (Mohanty, 2009). Thus entrepreneurship is generally considered as a power drive of any economy particularly because the recent global economic downturn has necessitated most developing nations of the world to consider entrepreneurship, precisely small and medium scale enterprises as the positive option for economic re-engineering and building (Lambing, and Kuehl, 2007).

\subsubsection{Women Entrepreneurship}

Women Entrepreneurs are described as a group of women who take initiative to establish and effectively run or manage businesses (Mohanty 2009). It is important to state that woman entrepreneurship is largely associated with small and medium enterprises consequent upon the fact that SMEs give women the opportunities to express their entrepreneurial talents hence their likelihood to be more involved in SMEs than their male counterparts (Tambunan, 2008).

\subsection{Economic Impact of Women Entrepreneurship}

Findings and research presented by the International Labour Office as regards female entrepreneurship in developing economies particularly in Africa, leads to substantial evidence that even women living under harsh and adverse conditions can still have notable economic impact by creating employment which most often than not is usually directed towards other women ( OECD, 2004)

Research findings indicated that a sample of 118 women entrepreneurs interviewed in Zambia owned 114 firms providing 1013 persons with employment (ILO, 2003). Another research statistics with relevance to women entrepreneurship in Africa also indicated that a sample of 128 women entrepreneurs interviewed in Tanzania provided 752 persons with jobs (OECD, 2004; ILO, 2003b). In the same vein 123 women entrepreneurs were interviewed in Ethiopia, these women owned firms that provided employment for 852 individuals.

These research findings above strongly indicate that women entrepreneurs particularly in developing countries have a potential and capacity to expand their enterprises thus facilitating job creation and economic development. Therefore the impact of women entrepreneurship cannot be overemphasized hence it is imperative to review obstacles impeding the development of women entrepreneurship targeted at fostering entrepreneurial activities particularly in Africa and other developing Nations.

\section{Theoretical Framework}

\subsection{Mansor Theory}

According to Mansor (2005) financial, environmental, psychological, and sociological factors are elements that are able to either encourage or discourage women in entrepreneurship (Moses, Olokundun and Akinbode 2014). Hence women entrepreneurial motivation is considered as an interaction between economical, social, psychological and environmental factors as well as a willingness on the part women to venture into entrepreneurial activity (Mansor, 2005 ; Moses, Olokundun and Akinbode 2014). Thus financial factors, may include insufficient finance, deterrents of tax system, inhibiting consequences of red-tapism and regulations, failure in policy implementation as regards promotion of small businesses, lack of prior financial education and experience, and other relevant factors (Mansor, 2005 ; Moses, Olokundun and Akinbode 2014). Environmental factors consist of availability of venture capital, presence of experienced 
entrepreneurs as well as technically skilled labour force, accessibility of suppliers and customers or new markets, government influences, availability of land and other facilities, accessibility of transportation, supporting services and improved living and developmental conditions of local communities ( Mansor, 2005 ; Moses, Olokundun and Akinbode 2014). In the same vein psychological factors may include capacity and inclination to risk as regards venture creation, internal locus of control, need for achievement, and being proactively disposed. Finally sociological factors may include; family influence, role model, and specifically the role of women in the society. Hence Mansor (2005) contended that the presence of these factors motivate the readiness to venture into entrepreneurial activity. Thus this study stems from the theoretical underpinning of Mansor's theory as a basis for articulating the challenges facing female entrepreneurs as presented in this study.

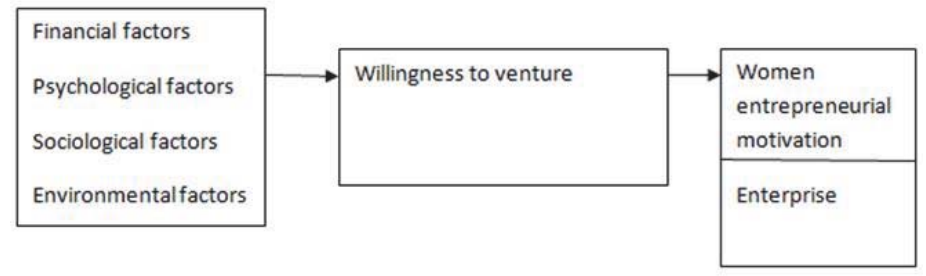

Figure 1: A Framework for Describing Women Entrepreneurial Motivation, Motivational Factors Capability Outcome A Framework for Describing Women Entrepreneurial Motivation Source: Mansor (2005)

\section{Methodology}

This study was based on a review of relevant literature targeted at identifying the challenges faced by women entrepreneurs in developing nations as well as the possible strategies that could be adopted in a bid to tackle these challenges. Thus the next section summarizes the above as reviewed from extant literature.

\subsection{Obstacles Facing the Development of Female Entrepreneurship}

Considering the importance of female entrepreneurship to potential job creation and economic development in developing worlds, it is very necessary to review different barriers women might face while engaging in the entrepreneurial process. These barriers include:

\subsection{Lack of Entrepreneurial Role Models}

There is a strong correlation between the presence of role models and the development of entrepreneurial competence in individuals, therefore the display of successful entrepreneurial attitudes and behaviour by role models establishes a desirability and acceptance of entrepreneurship as a career option by individuals ( Shapero and Sokol, 1982).

With particular regard to women entrepreneurship, the influence of role models is also believed to have a gender bias particularly because individuals have a tendency to be influenced by the aspirations and choices of individuals of the same sex (Deaux and Lafrance, 1998). This suggests that the successful entrepreneurial attitudes and activities of role model women entrepreneurs will greatly influence women to opt for entrepreneurship as a viable career choice.

However, the presence of role models in women entrepreneurship is lacking in developing Nations where the percentage of entrepreneurial activities of women is still very low compared to their male counterparts which accounts for the low entrepreneurial motivation and acceptance of entrepreneurship as a viable career option in women particularly in developing countries (OECD, 2004).

\subsection{Lack of Work Experience}

The entrepreneurship process largely depends on relevant experience, this is supported by the theory of human capital suggests that the achievement of higher performance by individuals as regards the completion of work related tasks is a function of the quality of human capital possessed by the individuals (Shane and Vankataraman, 2000)

In this context human capital refers to the relevant skills and knowledge possessed by individuals geared at 
successfully identifying and exploiting business opportunities hence the disparity between individuals as regards their abilities to identify and exploit business opportunities is largely a function of prior education and work experience (Shane, 2000).

However women in developing nations particularly in Africa are disadvantaged as regards acquisition of relevant education and work experience which is often due to cultural and religious reasons, this informs why women in developing nations lack the experience required to successfully identify and exploit business opportunities, thus a deterrent to the development of female entrepreneurship in these countries (OECD, 2004).

\subsection{Lack of Relevant Social Networks and Societal Positions}

Social networks represent structures and processes describing how individuals are linked with each other and the relationship between individuals in the network respectively (Larson and Starr 1993). An individual's social position or relevance is largely dependent on the individual's social networks, thus with relevance to entrepreneurship, interpersonal relationships differ in quality and quantity which directly impacts on successful venture start ups by individuals ( Malecki 1994)

Social networks are of utmost importance particularly because the actions of individuals are primarily a reflection of their social contexts or the circle of individuals they interact with (Hansen 1995). Thus an individual's network provides the necessary support vital to engaging in entrepreneurial activities successfully (Matthews and Moser, 1995).

However women particularly in developing nations generally have lower social positions than men which also reflect in the networks they have access to (Burt 2000). The networks women in developing countries are involved in are usually a reflection of personal and traditional networks which at best facilitates family related tasks which may not support business purposes (Lin, 1999). Therefore women in these countries have limited access to relevant resources, support and information provided by social networks which is required for venture start ups and management (OECD 2004).

\subsection{Lack of Capital Assets}

One of the key requirements for starting a business is to have adequate financial assets and the relevant knowledge assets (OECD 2004). Women's position particularly in developing nations makes it difficult to acquire both assets categories especially considering the fact that family obligations constrain women to work at full time jobs or to engage in a career (Mahbub, 2000). Consequently job opportunities for women in developing nations experience a downturn with reference to high paying jobs hence at best most women in these nations take up part time jobs or low paying jobs which are not consistent with the creation of personal wealth hence wealth required for women to engage in entrepreneurial activities is usually lacking particularly in developing countries (ILO, 2006).

\section{Policy Recommendations}

The following features a policy framework to support women entrepreneurship in developing nations:

\subsection{Increased Women Participation in the Labour Force}

Increasing the participation of women in the labour force can enhance the development of women entrepreneurship in developing nations. Women participation in the labour force can be enhanced by promoting policies of fair and equal treatment in the workplace (Taylor, 1998). Regarding family obligations such as child care, child care centres could be established in workplaces at affordable costs to enhance concentration at work (Fierrman (Zellner, 1994). The aim would be to afford women the work place experience and financial capability required to engage in entrepreneurial activities. This would increase the number of women adequately prepared for launching their business ventures

\subsection{Giving Prominence to Women Entrepreneurship}

Increased focus on the activities of women entrepreneurs would go a long way to facilitate the development of women entrepreneurship in developing countries (Kjeldsen and Nielson 2000). Government offices for women entrepreneurship could be established. This would enhance the organization of workshops and seminars for women entrepreneurs targeted at disseminating information and knowledge towards improving and developing women entrepreneurship in 
developing nations. This will facilitate entrepreneurial human capital development in women in these countries (Bartlett \& Bukvic, 2001). This in turn affords women the required education necessary for engaging in entrepreneurial activities.

\subsection{Promoting Women Entrepreneur Network}

The development of women entrepreneur networks is pivotal to the advancement of women entrepreneurship in developing nations (Kjeldsen and Nielson 2000). Women entrepreneur networks would go a long way to provide valuable sources of information and knowledge about women entrepreneurship and important ingredients for its development (Mansor, 2005). National and international networks could facilitate cooperation and partnerships that would enhance increased women entrepreneurial activities particularly in developing nations. Furthermore Government policies should accommodate more women in political positions; this will improve the societal status and positions of women which would also have a positive impact on their social networks. This as earlier stated will provide the right support and interaction that could facilitate venture start ups and management.

\subsection{Periodic Evaluation of Sme Policies on the Success of Women Entrepreneurship}

A periodic evaluation of the impact of SME policies as regards women entrepreneurship is pertinent to the development of women entrepreneurship in developing nations (Mohanty, 2009). The goal would be to highlight the policies that should be retained and how to improve them for enhanced effectiveness. For instance policy framework for SME financing should accommodate easy access to funds particularly for women entrepreneurs. This would be aimed at encouraging women to engage more in entrepreneurial activities.

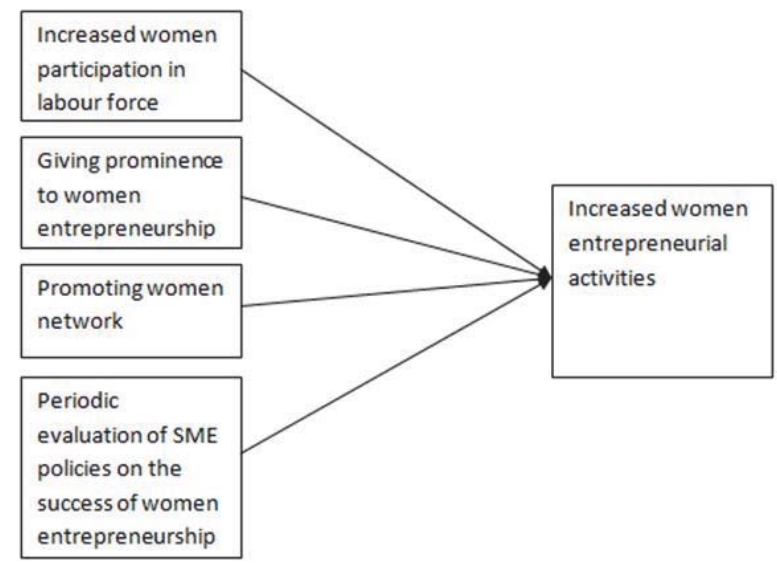

Figure 2: A Conceptual model on the factors that enhance increased female entrepreneurship in developing nations

\section{Conclusion}

This study reviewed the obstacles and constraints facing women entrepreneurs in most developing nations of the world. Considering the impact of women entrepreneurship to job creation and economic development as well as the promotion of entrepreneurial activities in these countries there is a need to create an enabling or favourable environment geared at motivating women towards the expression of entrepreneurial related behaviour. Women should have access to resources and markets as well as actual ownership and control of businesses (Mohanty 2009). Carr and Chen (2004) argued that there is no one time remedy that will sufficiently combat the multifaceted jumble of challenges that impede the development of women entrepreneurship. Thus economic policies and legal structures are advocated as remedies to tackle the challenges of women entrepreneurs particularly in developing nations. Thus policy makers in these nations are encouraged to develop strategic policies and programmes geared at capacity building for women entrepreneurs particularly because there is a direct relationship between women participation in entrepreneurial activities and a country's economic development. 


\section{References}

Acs, Z, Arenius, P., Hay, M. and Minniti, M. (2005) 2004 Global Entrepreneurship Monitor- Exclusive Report, London Business School, London and Babson College, Babson Park, MA.

Bartlett, W. \& Bukvic, V. (2001), Barriers to SME growth in Slovenia. MOCT-MOST: Economic Policy in Transitional Economies, Volume 11 pp. 177-195.

Baughn, C., Chua, B.L. and Neupert, K. (2006), "The normative context for women's participation in entrepreneurship: a multi-country study", Entrepreneurship Theory \& Practice, Vol. 30 No. 5, pp. 687-708.

Becker, G.S. 1964. Human Capital. Chicago: University of Chicago Press.

Burt, R.S. 200. The network entrepreneur. In R. Swedberg (Ed.), Entrepreneurship: The Social Science View: 281-307. Oxford: England: Oxford University Press.

Carr, M. \& Chen, M. (2004), Globalization, social exclusion and gender, International Labour Review, Vol. 143, No.1-2, pp. 129-160.

Deaux, K., \& Lafrance, M. 1998. Gender. In D.T. Gilbert, S.T. Fiske, \& G. Lindzey (Eds.), The Handbook of Social Psychology, Vol. 1 : 788-827. Boston: McGraw Hill.

Fierman, S. (1990). Peasant Intellectuals: Anthropology and History in Tanzania. Wisconsin Madson: University of Wisconsin Press.

Fuller-Love, N. (2006), Management development in small firms, International Journal of Management reviews, Volume 8, Issue 3, p. $175-190$.

Hansen., E.L. 1995. Entrepreneurial network and new organizational growth. Entrepreneurship Theory and Practice, 19(4): 7-19

Hisrich, R.D., Peters M.P. \& Shepherd D. A. (2006), Entrepreneurship, 7th ed., Boston: McGraw Hill.

ILO, (2006). Vulnerability and young women Entrepreneurs: A case study of Ethiopian Informal Economy. Geneva: International Labor Organization

Jamali, D. (2009), Constraints and Opportunities Facing Women Entrepreneurs in Developing Countries: A relational Perspective, Gender in Management: An International Journal, Vol. 24 No.4, pp 232 -251.

Kjeldsen J. and Nielson K. (2000). "The Circumstances of Women Entrepreneurs" Danish Agency for Trade and Industry, November. http://www.ebst.dk/publikationer/rapporter/womenentrepreneurs/kap04.html

Lambing, P.A. \& Kuehl, C.R. (2007), Entrepreneurship, 4th ed., New Jersey: Prentice Hall.

Langowitz, N. and Minniti, M. (2007), "The entrepreneurial propensity of women" Entrepreneurship Theory \& Practice, Vol. 31 No.3, pp. 581-94.

Larson, A., \& Starr, J.A. 1993. A network model of organizational formation. Entrepreneurship Theory \& Practice, 17(2): 5-15.

Lin, N. 1999. Social networks and status attainment. Annual Review of Sociology, 25: 467- 487.

Mahbub, U.H. (2000). Human Development Centre, Human Development in South Asia: The Gender Question (Oxford University Press).

Malecki, E.J. 1994. Entrepreneurship in regional and local development. International Regional Science Review, 16(1): 119-153.

Mansor, N. (2005). "Women in Business: Determinants for Venturing in Malaysians SMEs", www.tbs.ubbc/uj.ro/studia/articol_4_2_2005.

Mattthews, C.H., \& Moser, S.B. 1995. Family Background and gender: implications for interest in small firm ownership. Entrepreneurship \& Regional Development, $7: 365-377$.

Mohanty, S.K. (2009), Fundamentals of entrepreneurship, New Delhi: PHI Learning

Moses, C.L., Olokundun, M.A., and Akinbode, M. (2014). Determining Women Entrepreneurial Motivation: A Review Of Theoretical Models. International Journal of Small Business and Entrepreneurship Research Vol.2, No.3, pp.43-54

OECD (2004). Women's Entrepreneurship: Issues and Policies. 2 ${ }^{\text {nd }}$ OECD Conference of Ministers Responsible For Small and MediumSized Enterprises (SMEs). Promoting Entrepreneurship and Innovative SMEs in Global Economy: Towards a Responsible and Inclusive Globalisation. Istanbul Turkey

Shapero, A., \& Sokol, L. 1982. The social dimensions of entrepreneurship. In C.A. Kent, D.L. Sexton, \& K.H. Vesper (Eds), Encylopedia of Entrepreneurship: 72-90. Engelswoods Cliffs, NJ: Prentice-Hall.

Shane S. 2000. Prior Knowledge and the discovery of entrepreneurial opportunities. Organization Science. 11(4): 448-469.

Shane, S., and Venkataraman, S. (2000). The Promise of Entrepreneurship As A Field Of Research.Academy of Management Review, 25(1): 217-226.

Taylor, R. (1988). Exceptional Entrepreneurial Women: Strategies for Success, New York: Plenum Press.

Tambunan, T. T.H. (2008), Development of SMEs in ASEAN, Readworthy Publications, Ltd, New Delhi. 